ican and to every collaborating brother of a noble profession now gathered here from foreign lands, to every one within sound of my voice, to join with me in a cordial "All Hail!" to the coming centuries, not only in America but in every civilized spot of God's earth, because everywhere, to all coming time, human life will be lengthened, made more healthy, and consequently more truly happy, by the potent influences of state preventive medicine.

\title{
ABSTRAC' OF THE ADDRESS ON MEDICINE
}

DELIVERED BEFORE THE INTERNATIONAL MEDICAL CONGRESS AT PHILADELIHIA.

DY PROF. AUBTIN FLINT.

Dr. Fuint recalled to the minds of his audience that one hundred years ago there were two embryonic medical schools in America, one in Philadelphia and one in New York. A few years later we were separated from the mother country by Cæsarean section, and plunged into war. 'This war called out the medical energies of the colonies, but arrested medical teaching for some years. The leading medical minds were then principally in Philadelphia, New York, and Boston. After the war, Franklin interested himself in founding the Philadelphia Medical College, the meetings of the founders being held at his house until within two months of his death. In 1791 this school was merged into the medical department of the University of Pennsylvania. This latter school was modeled after the school of Edinburgh, and that after the Leyden school. All the professors of the Philadelphia school had been educated in Edinburgh. Rush was then the leading American medical mind. He wrote original treatises and edited foreign works, especially Cullen's work, which was widely read. This shows the activity of medicine at this period. The war, the great need of medical men, and the return of the many who had studied abroad, all combined to force the growth of medicine in America.

Philadelphia inaugurated medical teaching in this country. She was then and is now the great medical centre, and still has no compeer, in literature, teaching, or physicians. She has had a great influence on other cities of the Union. If this influence ceases in the future it will not be because she has weakened, but because of the emulation awakened by her example. It is fitting, then, that the congress should meet here.

At the end of the first quarter of the nineteenth century there were twenty medical schools and two thousand students in the United States. Six of these schools were metropolitan, in Philadelphia, New York, and Boston; fourteen of them were provincial. The latter met the needs of students unable to bear the expense of city tuition. They developed inquiry among physicians in their neighborhood and incited them to 
become teachers. Thus their influence was good. There was great jealousy among schools at this time. The first two graduates from Harvard met great opposition, and received their diplomas only through the influence of Dr. Jolin Warren.

At this period there were twenty medical journals. Even now their number is only doubled. Locally they are generally in the interest of some particular school, but they are useful in distributing medical intelligence, and journals relatively obscure have been the media of publication of papers of great value.

It may be said of the profession in America that they have ever been fraternal. May we not claim for medicine that it has raised physicians above the influence of politics? Even the late war did not disturb tho strong feeling of friendship between Northern and Southern medical men.

Referring to important agencies in the growth of medicine, Dr. Flint mentioned Cullen as the strongest pathologist at the close of the last century. Following him came Rush, then Good, each having an original system; then Brown, of Edinburgh, the opponent of Cullen. There was at this time no leading system. Rush, Cullen, and Good were the predominant minds, but neither was followed exclusively. In 1801 Valentine Seaman, of New York, began vaccination. In 1817 the Pharmacopocia was projected, and it was published in 1820. In 1846 anæsthetics were first used in Boston, and afterwards introduced into England and the Continent.

Dr. Flint then referred to the many foreign books translated and edited by Americnns which have aided medicine in America. In 1829 the first native work on pathological anatomy was published by Horner, and later Gross's work appeared. They were the pioneers. J. B. S. Jackson unfortunately, if not blamably, became satisfied with his position as professor in a leading school and curator of a museum rich in specimens. He might have been. more permanently identified with pathology in this and in every other country.

Dr. Flint next referred to auscultation, making honorable mention of James Jackson in connection with the discovery of the significance of prolonged expiration; also mentioning Dr. Holmes as having taken the Boylston prize for an essay on auscultation.

In the diagnosis of heart diseases American physicians were aided by the works of Hope, Andre, Stokes, and others. Bowditch and Gerhard also made us familiar with this science. Referring to Bright's clinical reports, Dr. Flint said that Bright could not have anticipated the advance in the diagnosis of renal disease to which we have attained in the present quarter of the century.

In the second quarter of the nineteenth century Hayes's American Journal of the Medical Sciences first appeared, promising translations of 
all important foreign medical.intelligence, and valuable original articles. It has kept and still keeps the promise, and is the oldest medical publication in this country, having also the largest circulation of any similar publication in the world. Dr. Flint then made flattering mention of the earnest and prolonged experiments of Beaumont upon St. Martin.

Broussais's works, translated by Hays and Griffiths, won many disciples to Broussaisism. This was the last of the legitimate 'isms, and has given way to illegitimate 'pathies. Dr. Flint next mentioned the work of Cook, who believed congestion of the liver to be the fons et origo of all disease. Alluding to the Kentucky practice of giving huge doses of calomel in affections of the liver, the speaker told the story of a yeoman, who, while plowing his field, came upon a quantity of metallic mercury and supposed he had struck a mine of wealth, but became quite chop-fallen when told that he had simply plowed up the spot formerly used as the burial-place of patients who had been subjected to mercurial treatment.

The powerful influence and the present worth of the works of Louis and his new departure in methods of study were mentioned.

Jacob Bigelow in 1835 struck the key-note of change in the treatment of disease in his work on Self-Limiting Diseases. Polypharmacy and heroic mensures fell into disrepute. Physicians became more reserved and humbly changed to servants of nature. In 1833 appeared the United States Dispensatory of Wood and Bache. In 1847 the. American Medical Association was inaugurated for the protection of the profession and for the advancement of knowledge. Allusion was made to the valuable paper of Nathan Sinith on typhus. At this time the non-identity of eruptive fevers was accepted as a fact.

In 1846 Meredith Clymer was the first to discover and describe relapsing fever. Dickson and Drake announced their belief in the conjoined action of different morbid influences at the same time in the same person. John Ware innugurated the numerical method in the use of opium. The large use of opium in peritonitis was referred to as the American method of treatment of this disease. Bowditch in this quarter of the century invented the operation of paracentesis thoracis, and altbough we now say aspiration in place of suction, using complicated foreign instruments in this procedure, the operation in its origin is American.

Dr. Flint then read the long list of American authors who wrote during the fourscore years following the Declaration of Independence, and asked, "Was not the advance of literature in this country in less than eighty years remarkable?"

Coming down to the last quarter of the century the speaker alluded to some of the characteristics of progress in medical science in America, the advance in histology and pathology, the use of the microscope (refer- 
ring here to the brilliant paper on the micioscope of Burnett in 1851), the great influence of German medical literature in the direction of pathologv, the fondness of Americans for foreign schools, and the unwise prejudice of some persons against this inclination to study in European schools. We should be humble in our relations with the schools of Europe, yet no student from abroad, who has remained the mere satellite of his foreign master, has ever attained clistinction.

Reference was then made to the injustice of the non-existence of a copyright law. Republication of French works in translation has become unnecessary because of the present general knowledge of the original. A similar knowledge of the German language it is hoped will soon be as general.

Our literature has been fairly treated and well received abroad. Our works are practical in charncter because we are young. The leading characteristic of our medical schools is practicality. 'The responsibility for the character of our profession rests upon the tenchers in our schools. The public is practically unprotected by law against practitioners who have no diplomas. We have large schools. They are an indication of progress. Let us try to correct defects, let us improve our methods of teaching, but avoid wholesale condemnation of what has been done. Of our code of ethics Dr. Flint asked what it is and what it does. It has remained unaltered during the past twenty-five years. This reflects honor on the profession. We may claim that the majority of physicians liave been honorable. In no other country is the dividing line between illegitimate and legitimate practitioners more sharply drawn than in ours, because in no other country do medical men occupy so high a social grade.

The history of American medicine contains much of which we may be proud. Need we doubt that the spirit thus far shown will lead to a glorious destiny?

\section{RECEN'T PROGRESS IN ANATOMY.'}

BX THOMAS DWIGIT, M. D.

Connective Tissue. ${ }^{2}$ - Professor Flemming, of Prague, has added a long and valuable cominunication to the already rich literature of this subject. He has devoted himself especially to loose connective tissue as it is found under the skin and in the interspaces between muscles, and to fat cells. Connective tissue is generally held to consist of fibres and cells. The latter are of various kinds, and in certain places are ranged around bundles of fibres in a way to form more or less perfect sheaths. Professor Flemming adds another element which indeed has

1 Concluded from page 292.

2 Archiv lïr mikroskopische Anatomie, Band zii., Heft 3, 1876. 